International Journal of Instruction e-ISSN: 1308-1470 • www.e-iji.net

Article submission code 20200303004618

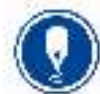

January $2021 \bullet$ Vol.14, No.1

p-ISSN: 1694-609X

pp. $983-998$

Received: 03/03/2020

Revision: 14/08/2020
Accepted: 05/09/2020

OnlineFirst: 12/12/2020

\title{
Formative Assessment as a Predictor of Mathematics Teachers' Levels of Metacognitive Regulation
}

\section{Ruth Nanjekho Wafubwa}

Doctoral School of Education, Faculty of Humanities and Social Sciences, University of Szeged-Hungary, Hungary, ruthnanje@gmail.com

\section{Csaba Csíkos}

ELTE, Eötvös Loránd University, Faculty of Primary and Pre-School Education, Budapest-Hungary, Hungary, csikos.csaba@tok.elte.hu

This study investigated the relationship between mathematics teachers' perceived use of formative assessment strategies and their levels of metacognitive regulation. The study employed a descriptive cross-sectional survey design using a sample of 213 (male=138; female=42) mathematics secondary school teachers from 50 randomly selected secondary schools in Kenya. The Teacher Assessment for Learning Questionnaire (TAFL-Q) was used to measures the mathematics teachers' perceptions of formative assessment whereas the Metacognitive regulation Inventory for Teachers (MAIT) scale was used to measure mathematics teachers' levels of metacognitive regulation. The relationship between the two scales was modeled using structural equation modeling and path analysis in AMOS graphics software. The measurement model fitted the data well with acceptable fit indices. The results of the model show that teachers evaluating skills are positively predicted by learning intentions, success criteria, and peer assessment. Monitoring skills are positively predicted by classroom discussion and peer assessment. Planning skills, on the other hand, are positively predicted by feedback, peer assessment, and success criteria. This study contributes to the limited literature regarding the relationship between formative assessment and metacognition. Teachers' understanding of this relationship will help in modeling learning strategies and skills in the learners.

Keywords: formative assessment, metacognitive regulation, secondary schools, mathematics teachers, structural equation modeling

\section{INTRODUCTION}

The emergence of $21^{\text {st }}$-century competencies has come along with challenges of teaching and assessing them (Lai \& Viering (2012). One of the ways that have been deemed suitable for teaching and assessing these competencies is by using formative assessment strategies (Shute \& Becker, 2010; Griffin \& Care, 2013). The benefits of formative

Citation: Wafubwa, R. N., \& Csíkos, C. (2021). Formative Assessment as a Predictor of Mathematics Teachers' Levels of Metacognitive Regulation. International Journal of Instruction, 14(1), 983-998. https://doi.org/10.29333/iji.2021.14158a 
assessment cannot be overemphasized. Studies have shown that formative assessment benefits both teachers and learners. Unlike summative assessment which is used as a measurement instrument, formative assessment is designed to support teaching and can, therefore, be used as a teaching tool (Clark, 2012; Gipps, Hargreaves \& McCallum, 2015). Teachers who use formative assessment strategies such as classroom discussions, questioning, effective feedback, self-assessment, and peer assessment (Black \& Wiliam, 2009) enhance student achievement. Formative assessment also acts as a valuable professional development opportunity for teachers (OECD, 2005) since teachers need to optimize their content knowledge to apply quality and effective formative assessment strategies (Heritage, 2007; Sadler, 2009).

The main goal of formative assessment has been seen as promoting students' learning to learn skills (OECD, 2005). Formative assessment also builds students' skills at peerassessment and self-assessment and helps students to develop a range of effective learning strategies (Chan, 2010). When students actively build their understanding, they develop invaluable skills for lifelong learning. Formative assessment thus enables students to become autonomous and self-regulating learners. According to Vrugt and Oort (2008), self-regulation (metacognitive regulation) is an important aspect of learning in academic performance because learners are actively engaged in the learning process. Shepard (2006) too noted that formative assessment encourages students' metacognition and reflection in their learning. As teachers clarify learning intentions and criteria for success through feedback, students can regulate their learning and become partners in filling the learning gaps (Heritage, 2007). It is therefore important to teach students metacognitive strategies so that they construct their understanding through deep learning. Teachers can only teach students metacognitive strategies if they are metacognitive in their teaching. In other words, teachers must also become learners for learning to be visible (Hattie \& Yates, 2013). Metacognition enables teachers to be aware of their strengths and weaknesses and can, therefore, be more effective in their teaching (Ben-David \& Orion, 2013).

\section{THEORETICAL BACKGROUND}

\section{Formative assessment}

Formative assessment as a classroom practice came into the limelight following the seminal work of Black and Wiliam (1998) which involved the synthesis of over 250 studies, linking assessment and learning. Black and Wiliam (2009) after considering the main features of teaching and learning defined formative assessment as:

Practice in a classroom is formative to the extent that evidence about student achievement is elicited, interpreted, and used by teachers, learners, or their peers, to make decisions about the next steps in instruction that are likely to be better, or better founded, than the decisions they would have taken in the absence of the evidence that was elicited (Black \& Wiliam 2009 p. 9).

Wiliam (2011) noted that the basic idea behind formative assessment is that evidence of student learning is used to adjust instruction to better meet students' learning needs. Formative assessment is thus designed to support teaching and learning continuously 
(Clark, 2012; Gipps, et al., 2015). To meet students' learning needs, Black and Wiliam (2009) identified five key strategies that could be used in classrooms as involving: learning intentions and criteria for success, classroom discussions, feedback, peer assessment and self-assessment. Research has shown that formative assessment practices such as self and peer assessment have a positive impact on self-regulated learning (Zimmerman \& Schunk 2011; Panadero \& Alonso-Tapia 2014; Panadero \& Broadbent, 2018). Generally, studies agree that formative assessment plays a role in self-regulated learning. Notwithstanding, some aspects of formative assessment have not been studied empirically. Borrowing from Black and Wiliam (2009) framework of formative assessment, Pat-El, Tillema, Segers, and Vedder (2013) conceptualized formative assessment (assessment for learning) as comprising of monitoring and scaffolding dimensions. They viewed the monitoring dimension as consisting of strategies that deal with feedback and self-monitoring whereas the scaffolding dimension deals with instruction related processes such as classroom questioning. As noted by Lee and mark (2014), monitoring strategies entails students examining their learning progress through self-monitoring to identify learning strengths and weaknesses. Scaffolding, on the other hand, involves a classroom interaction through sharing learning intentions, success criteria, and how success is evaluated (Pat-El, Tillema, Segers, \& Vedder, 2015).

\section{Metacognition}

Metacognition was originally defined by Flavell (1979) and Brown (1978) as the knowledge about and regulation of one's cognitive activities in the learning processes (in Veenman, Van Hout-Wolters \& Afflerbach, 2006). Since then, metacognition has been substantively studied in the field of educational psychology and has been often seen as a form of executive control involving monitoring and self-regulation (Demetriou, Spanoudis, \& Mouyi, 2011). Based on Flavell's definition, most researchers have conceptualized metacognition as consisting of two broad dimensions: knowledge about cognition and regulation of cognition (e.g., Williams \& Atkins, 2009; Veenman, 2011; Lai \& Viering, 2012). Knowledge of cognition also referred to as knowledge and awareness of one's cognition is composed of declarative, procedural, and conditional knowledge (Harris, Santangelo \& Graham, 2010). Declarative knowledge is the kind of knowledge required to accomplish a task; Procedural knowledge deals with how to apply learning strategies; whereas Conditional knowledge relates to knowledge of when, where, and why in applying particular procedures or strategies (Harris et al., 2010; Mahdavi, 2014).

Regulation of cognition or metacognitive skills is described as an acquired repertoire of procedural knowledge for monitoring, guiding, and controlling one's learning and problem-solving behavior (Veenman, 2011). Planning involves choosing relevant strategies and providing the required resources to attain the learning goals; Monitoring refers to skills necessary to regulate one's learning like self-assessment skills; while Evaluation refers to the process of judging the achievements made (Harris et al., 2010; Mahdavi, 2014). Metacognitive skills play a great role in guiding and controlling the execution of tasks (Veenman, 2011). Studies have further shown that metacognitive skills training greatly improve the performance of students (Kramarski \& Mevarech, 
2003; Veenman et al., 2006; Mevarech \& Fridkin, 2006). Through metacognitive skills, learners are therefore able to often carry out self-evaluation of task performance, selfmonitoring, and planning. An intervention study by Csíkos and Steklács (2010) focusing on planning, monitoring, and evaluation skills resulted in a positive achievement among the Hungarian students. Other intervention studies with similar outcomes include Roll, Aleven, McLaren, and Koedinger (2011) and, Naseri, Kazemi, and Motlag (2017).

\section{Formative assessment and metacognition}

Whereas a substantial number of studies have shown that student metacognitive skills training leads to a positive outcome, little is known about what influences teachers' metacognition. As much as studies strongly advocate that students should be made aware of the importance of metacognition through ways such as teacher's modeling (Martinez, 2006; Tanner, 2012), it has also been noted that teachers lack adequate knowledge about metacognition and they, therefore, need to be trained on metacognitive instruction (Veenman et al., 2006). Enhancing awareness, improving self-knowledge, and ensuring conducive learning environments have been described by Schraw (1998) as some of the instructional strategies for promoting metacognitive awareness.

In enhancing general awareness, Schraw (1998) pointed out the important role played by the teacher and other students in modeling cognitive and metacognitive skills. This implies that both teachers and learners work together in designing the learning intentions and success criteria. In the formative assessment framework by Black and Wiliam (2009), clarifying learning intentions and criteria for success is the first strategy that points to where the leaner is going. This is jointly done by the teacher, the learner, and the peer. Schraw further noted that students should be given a chance to regularly reflect on their drawbacks and achievements. This involves self and peer assessment through discussions and teachers' feedback.

According to the formative assessment framework by Black and Wiliam (2009), the learning gap can be filled through strategies like effective classroom discussions, feedback, peer assessment, and self-assessment (Braund \& DeLuca, 2018). Formative assessment is hence a learning process that can enhance students' metacognitive knowledge. Theoretically, metacognition is seen as a multidimensional set of general skills that are crucial for developing $21^{\text {st }}$-century skills and competencies (Lai \& Viering, 2012). However, few empirical studies have investigated the relationship between formative assessment and metacognition. Baas, Castelijns, Vermeulen, Martens, \& Segers (2014) investigated the relationship between assessment for learning (formative assessment) and metacognition among elementary school students. The results showed that formative assessment strategies involving monitoring and scaffolding predicted the students' use of cognitive and metacognitive strategies.

\section{The current study}

The preceding literature has illustrated how the aspects of formative assessment relate to metacognition especially the regulation of cognition. Limited empirical research has however been done to show a clear relationship between formative assessment and metacognition. This study aims to fill the gap regarding the limited literature by empirically examining the relationship between teachers' perceptions of formative 
assessment and their levels of metacognitive skills. We aim to show how the use of formative assessment strategies affects the teachers' metacognitive regulation in terms of planning, monitoring, and evaluating skills (Balcikanli, 2011). Based on the literature review, we hypothesized that the use of formative assessment strategies will have a positive effect on teachers' levels of metacognitive skills. This study, therefore, sought to answer the research question: "what is the relationship between mathematics teachers' formative assessment strategy use and their levels of metacognitive regulation?"

\section{METHOD}

\section{Sample}

There were two sets of samples consisting of 180 and 213 secondary school mathematics teachers from 50 secondary schools in Kenya. The two samples were collected in two different counties in Kenya. Stratified and simple random sampling techniques were employed to obtain a representative sample from different school categories. Table 1 gives a summary of the sample characteristics.

Table 1

Background information about the participants

\begin{tabular}{llllll}
\hline \multirow{2}{*}{ Demographics } & & \multicolumn{2}{c}{ Sample 1 } & \multicolumn{2}{c}{ Sample 2 } \\
\hline Gender & Description & $\mathrm{n}$ & $\%$ & $\mathrm{n}$ & $\%$ \\
\hline \multirow{2}{*}{ Teacher qualification } & Male & 138 & 76.7 & 157 & 73.7 \\
\cline { 2 - 6 } & Female & 42 & 23.3 & 56 & 26.3 \\
\cline { 2 - 6 } & B.Ed. & 143 & 79.4 & 166 & 77.9 \\
\cline { 2 - 6 } & BA/BSc & 14 & 7.8 & 19 & 8.9 \\
\cline { 2 - 6 } & Diploma & 21 & 11.7 & 25 & 11.7 \\
\cline { 2 - 6 } & M.Ed. & 2 & 1.1 & 3 & 1.4 \\
\hline Teaching experience & Up to 5 years & 109 & 60.6 & 125 & 58.7 \\
\cline { 2 - 6 } & 6 to 10 years & 21 & 17.2 & 41 & 17.2 \\
\cline { 2 - 6 } & 11 to 15 years & 32 & 12.2 & 27 & 12.7 \\
\cline { 2 - 6 } & Above 15 years & 18 & 10 & 20 & 9.4 \\
\hline
\end{tabular}

\section{Measures}

Questionnaires were used to measure the perceptions of mathematics teachers' use of formative assessment strategies and their levels of metacognitive regulation.

\section{Perception of formative assessment}

Teacher Assessment for Learning Questionnaire (TAFL-Q) was used to measure the teachers' perceptions of formative assessment. The TAFL-Q was constructed by Pat-El et al. (2013) using a sample of secondary school teachers from Netherland. The questionnaire consisted of 28 closed-ended items divided into two scales; perceived monitoring (16 items) and perceived scaffolding (12 items). The items were measured on a five-point Likert scale. The TAFL-Q was used in the current study without any modification on the items.

\section{Metacognitive awareness}

Metacognitive regulation Inventory for Teachers (MAIT) scale was used to measure the teachers' level of metacognitive awareness. The MAIT scale was constructed by 
Balcikanli (2011) who considered the two components of metacognition: metacognitive knowledge and metacognitive skills with three scales under each component. The scales under metacognitive knowledge included declarative knowledge (DK), procedural knowledge (PK), and conditional knowledge (CK). On the other hand, the scales under metacognitive regulation included planning $(\mathrm{P})$, monitoring $(\mathrm{M})$, and evaluating $(\mathrm{E})$. Each of the six scales was composed of four items which were measured on a five-point Likert scale. The present study only considered the component of metacognitive skills which had the scales of planning, monitoring, and evaluating.

\section{Data collection procedure and analysis}

After obtaining clearance from the Ministry of education, the researchers visited the sampled schools and physically delivered questionnaires to the teachers through the heads of mathematics departments. After being assured of anonymity of participation, each teacher took approximately 25 minutes to fill in the questionnaires. Confirmatory factor analysis was conducted using Amos Graphics 23 to test the model fit to the first sample $(n=180)$. Since the Teacher Assessment for Learning Questionnaire (TAFL-Q) had a poor fit, exploratory factor analysis was done using IBM SPSS Statistics 25 to obtain a new factor structure. Descriptive and inferential statistics were computed to analyze the data collected. Descriptive statistics were computed to obtain the participants' levels of agreement regarding formative assessment and metacognitive skills use. The relationship between the variables was measured using structural equation modeling (SEM) and analysis of moment structures (AMOS).

\section{FINDINGS}

\section{Measurement model development}

The assumptions of multivariate normality and linearity of the data from the TAFL-Q and MAIT were evaluated through IBM SPSS Statistics 25 based on Kline (2011) guidelines. Using Cook's distance and box plots, no significant univariate or multivariate outliers were observed. The data were normally distributed without any missing data. Maximum likelihood estimation was therefore used in the analysis.

\section{TAFL-Q Analysis}

A confirmatory factor analysis (CFA) was conducted on TAFL-Q using a sample of 180 mathematics teachers to see whether the model fits the questionnaire data of the Kenyan sample. The results showed a poor fit with the following fit indices: CMIN/DF $=2.643$, $\mathrm{RMSEA}=.096, \mathrm{SRMR}=.085, \mathrm{TLI}=.653, \mathrm{CFI}=.680$. It was, therefore, necessary to establish a new factor structure for the sample. Factor analysis by principal components analysis and Varimax Kaiser Normalization rotation resulted in a six-factor structure consisting of 19 items from the original 28 items. The nine items were eliminated after a careful analysis based on the guidelines suggested by Williams, Onsman, and Brown (2010).

The emergent six factors were: Perceived Learning Intentions (PLI); Perceived Feedback (PF); Perceived Classroom Discussion (PCD); Perceived Peer Assessment (PPA); Perceived Self-Assessment (PSA) and Perceived Success Criteria (PSC). These 
emergent factors are well supported by the formative assessment theoretical framework and were therefore labeled based on the strategies of formative assessment (Black \& Wiliam, 2009). Using a different sample of 213 secondary school mathematics teachers, the new version of the TAFL-Q resulted in an improved acceptable model with the following fit indices: $\mathrm{CMIN} / \mathrm{DF}=2.009, \mathrm{RMSEA}=.069, \mathrm{SRMR}=.054$, $\mathrm{TLI}=.862$, $\mathrm{CFI}=.889$. Although the values of the two incremental indices; TLI (0.862) and CFI (0.889) were slightly below the recommended threshold of 0.9 , they were still within the acceptable range (Ho, 2006).

\section{MAIT Analysis}

The MAIT consisted of six scales but CFA was conducted for three scales which represented the metacognitive regulation dimension because that was the area of our focus. The three scales of metacognitive regulation had a total of 12 items that measured planning, monitoring, and evaluating skills. The CFA resulted in an acceptable model on both samples that were used in this study. The fit indices for the first sample of 180 were: $\mathrm{CMIN} / \mathrm{DF}=2.275, \mathrm{RMSEA}=.084, \mathrm{SRMR}=.058, \mathrm{TLI}=.913, \mathrm{CFI}=.933$ while the second sample of 213 resulted to the following fit indices: CMIN/DF $=2.2411$, RMSEA $=.082$, SRMR $=.053$, TLI $=.917, \mathrm{CFI}=.936$. No item was therefore eliminated from the MAIT scale. The scales and reliabilities of the two instruments are shown in table 2.

Table 2

Scales, Cronbach's alphas and sample items for the TAFL-Q and MAIT $(n=213)$

\begin{tabular}{|c|c|c|c|c|}
\hline Scale & & $\mathrm{N}$ & $\alpha$ & Sample item \\
\hline \multirow[t]{6}{*}{ TAFL-Q } & $\begin{array}{l}\text { Perceived Learning } \\
\text { Intentions (PLI) }\end{array}$ & 3 & .70 & $\begin{array}{l}\text { After a test, I discuss the answer given } \\
\text { with each student }\end{array}$ \\
\hline & Perceived Feedback(PF) & 3 & .66 & $\begin{array}{l}\text { I inform my students on their strong points } \\
\text { concerning learning }\end{array}$ \\
\hline & $\begin{array}{l}\text { Perceived Classroom } \\
\text { Discussion (PCD }\end{array}$ & 3 & .68 & $\begin{array}{l}\text { I discuss with my students the progress } \\
\text { they have made }\end{array}$ \\
\hline & $\begin{array}{l}\text { Perceived Peer } \\
\text { Assessment (PPA }\end{array}$ & 3 & .76 & $\begin{array}{l}\text { I adjust my instructions whenever I notice } \\
\text { that my students do not understand a topic }\end{array}$ \\
\hline & $\begin{array}{l}\text { Perceived Self- } \\
\text { Assessment (PSA) }\end{array}$ & 3 & .74 & $\begin{array}{l}\text { I ask questions in a way my students } \\
\text { understand }\end{array}$ \\
\hline & $\begin{array}{l}\text { Perceived Success Criteria } \\
\text { (PSC) }\end{array}$ & 4 & .72 & $\begin{array}{l}\text { I allow my students to ask each other } \\
\text { questions during class }\end{array}$ \\
\hline \multirow{3}{*}{$\begin{array}{l}\text { MAIT } \\
\text { scale }\end{array}$} & Planning $(\mathrm{P})$ & 4 & .77 & I know what I am expected to teach \\
\hline & Monitoring (M) & 4 & .83 & $\begin{array}{l}\text { I try to use teaching techniques that } \\
\text { worked in the past }\end{array}$ \\
\hline & Evaluating (E) & 4 & .87 & $\begin{array}{l}\text { I have a specific reason for choosing each } \\
\text { teaching technique I use in class }\end{array}$ \\
\hline
\end{tabular}

\section{Final Model}

All the latent variables in the TAFL-Q and MAIT were considered in the final measurement model with a sample of 213 mathematics teachers. The model fit for the nine latent variables in the measurement model resulted to an adequate model fit for the 
data: $\mathrm{CMIN} / \mathrm{DF}=1.789, \mathrm{RMSEA}=.061, \mathrm{SRMR}=.055, \mathrm{CFI}=.879$. Table 3 shows the mean, standard deviation, and correlations among the latent variables. Analysis of the standardized residual matrix for the measurement model revealed no statistically significant residual (all absolute values were less than two).

Table 3

Means, standard deviations and correlations among the latent variables

\begin{tabular}{|c|c|c|c|c|c|c|c|c|c|c|c|}
\hline & Scale & $\mathrm{M}$ & SD & 1 & 2 & 3 & 4 & 5 & 6 & 7 & 8 \\
\hline 1 & PLI & 2.45 & .95 & & & & & & & & \\
\hline 2 & $\mathrm{PF}$ & 3.07 & .73 & $.31^{* * *}$ & & & & & & & \\
\hline 3 & PCD & 3.14 & .67 & $.35^{* * 2}$ & $.41^{* * *}$ & & & & & & \\
\hline 4 & PPA & 3.01 & .77 & $.35^{* * *}$ & $.49^{* * *}$ & $.46^{* * *}$ & & & & & \\
\hline 5 & PSA & 3.31 & .66 & .09 & $.36^{* * *}$ & $.39^{* * *}$ & $.47^{* * *}$ & & & & \\
\hline 6 & PSC & 2.81 & .78 & $.38^{* *}$ & $.34^{* * *}$ & $.38^{* * *}$ & $.47^{* *}$ & $.43^{* * *}$ & & & \\
\hline 7 & Planning & 2.90 & .81 & $.32^{* * *}$ & $.28^{* * *}$ & $.20^{* * *}$ & $.41^{* * *}$ & $.23^{* * *}$ & $.49^{* * 3}$ & & \\
\hline 8 & Monitoring & 3.05 & .83 & $.26^{* * *}$ & $.34^{* * *}$ & $.38^{* * *}$ & $.46^{* *}$ & $.34^{* * *}$ & $.47^{* *}$ & $.54^{* * *}$ & \\
\hline 9 & Evaluation & 2.67 & 1.05 & $.35^{* *}$ & $.26^{* * *}$ & $.32^{* * *}$ & $.52^{* *}$ & $.30^{* * *}$ & $.57^{* * *}$ & $.62^{* * *}$ & $.66^{* * *}$ \\
\hline
\end{tabular}

**. Correlation is significant at the 0.01 level (2-tailed).

\section{The Structural Model}

The final analysis involved testing the hypothesized structural relationships among the predictor and observed variables through bootstrapping analysis. Since the TAFL-Q did not fit the Kenyan data well, we had to obtain a new factor structure. The Kenyan sample disintegrated into a six-factor structure from the original two-factor structure. The hypothetical relationship is reflected in figure 1. The predictors of planning were hypothesized to be PLI, PF, PPA, and PSC; the predictors of monitoring were PLI and PF through planning, PCD, PPA, and PSC. The predictors of evaluating were PCD through monitoring, PPA, PSA, and PSC.

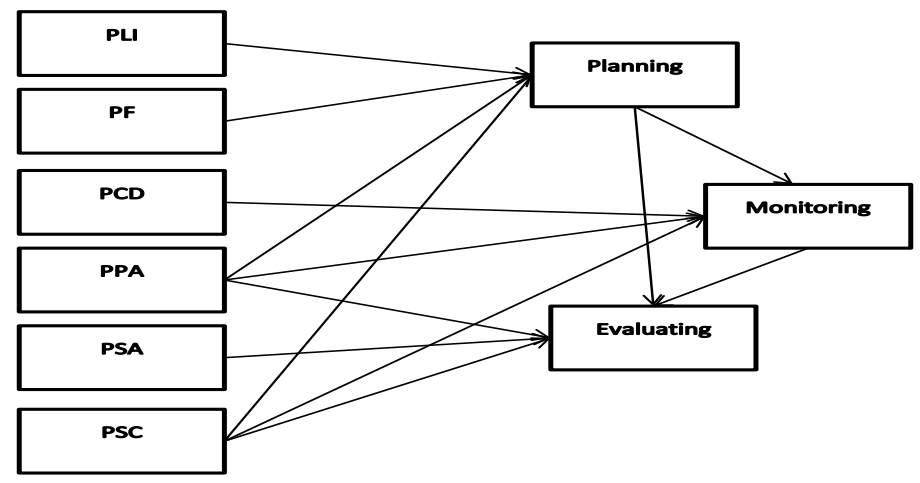

Figure 1

Hypothetical relationship between formative assessment strategies and metacognitive skills (PLI-perceived learning intentions; PF-perceived feedback; PCD- perceived classroom discussion; PPA-perceived peer assessment; PSA-perceived self-assessment; PSC-perceived success criteria) 
The hypothesized structural model fitted the data $(n=213)$ well with the following fit indices: $\mathrm{CMIN} / \mathrm{DF}=1.218, \mathrm{RMSEA}=.032, \mathrm{SRMR}=.012, \mathrm{TLI}=.989, \mathrm{CFI}=.998$. There were no post-hoc modifications from the analysis because the indices indicated a good fit between the model and the observed data. Furthermore, the residual analysis did not indicate any problems. Table 4 and Figure 2 show the results of the estimates for the parameters. Regression analysis (table 4) revealed significant path relations in almost all the predictors of metacognitive regulation (planning, monitoring, and evaluating). Only two paths; PSA to evaluating and PF to planning did not show a significant effect. Results of squared multiple correlations $\left(\mathrm{R}^{2}\right)$ showed that the predictors of Planning explained 33 percent of its variance; predictors of Monitoring explained 41 percent of its variance and the predictors of Evaluating explained 55 percent of its variance.

\section{Direct Effects}

The results show a direct positive effect of success criteria $(\beta=.17)$ and peer assessment $(\beta=.15)$ on evaluating skills; classroom discussion $(\beta=.16)$ and peer assessment $(\beta=.13)$ on monitoring skills; learning intentions $(\beta=.13)$, feedback $(\beta=.03)$, peer assessment $(\beta=.19)$ and success criteria $(\beta=.36)$ on planning skills. Self-assessment $(\beta=-.06)$ is however negatively related to evaluating skills. The effects of feedback $(\beta=.03)$ on planning; and self-assessment $(\beta=-.06)$ on evaluating were not significant $(\mathrm{p}>.05)$ as reflected in table 4 .

\section{Indirect Effects}

Significant mediated effects were found between PPA and monitoring through planning $(\beta=.027, \mathrm{p}<.05) ;$ PCD and evaluating through monitoring $(\beta=.033, \mathrm{p}<.05) ;$ PPA and evaluating through monitoring $(\beta=.009 \mathrm{p}<.01)$; PSC and monitoring through planning $(\beta=.011, \mathrm{p}<.01)$; PSC and evaluating through planning $(\beta=.008, \mathrm{p}<.01)$.

Table 4

Standardized and unstandardized coefficients of the structural model

\begin{tabular}{llllllll}
\hline Outcome & & Predictor & $B$ & $S E B$ & $\beta$ & $t$ & $P$ \\
\hline Planning & $<---$ & PPA & .166 & .064 & .186 & 2.576 & .010 \\
\hline Planning & $<---$ & PLI & .093 & .046 & .129 & 2.034 & .042 \\
\hline Planning & $<---$ & PF & .032 & .064 & .034 & .504 & .614 \\
\hline Planning & $<---$ & PSC & .321 & .060 & .363 & 5.316 & .000 \\
\hline Monitoring & $<---$ & Planning & .436 & .073 & .378 & 5.964 & .000 \\
\hline Monitoring & $<---$ & PCD & .156 & .071 & .135 & 2.191 & .028 \\
\hline Monitoring & $<---$ & PPA & .161 & .069 & .157 & 2.348 & .019 \\
\hline Monitoring & $<---$ & PSC & .155 & .069 & .152 & 2.247 & .025 \\
\hline Evaluating & $<---$ & PSC & .217 & .079 & .168 & 2.755 & .006 \\
\hline Evaluating & $<---$ & Monitoring & .488 & .076 & .385 & 6.453 & .000 \\
\hline Evaluating & $<---$ & PSA & -.092 & .086 & -.058 & -1.061 & .289 \\
\hline Evaluating & $<---$ & Planning & .360 & .088 & .246 & 4.090 & .000 \\
\hline Evaluating & $<---$ & PPA & .192 & .078 & .147 & 2.467 & .014
\end{tabular}

Note. $B$ =unstandardised beta; $S E B=$ standard error for unstandardised beta; $\beta$ $=$ standardised beta; $\mathrm{t}=\mathrm{t}$-test statistic; $\mathrm{p}=$ probability value. 


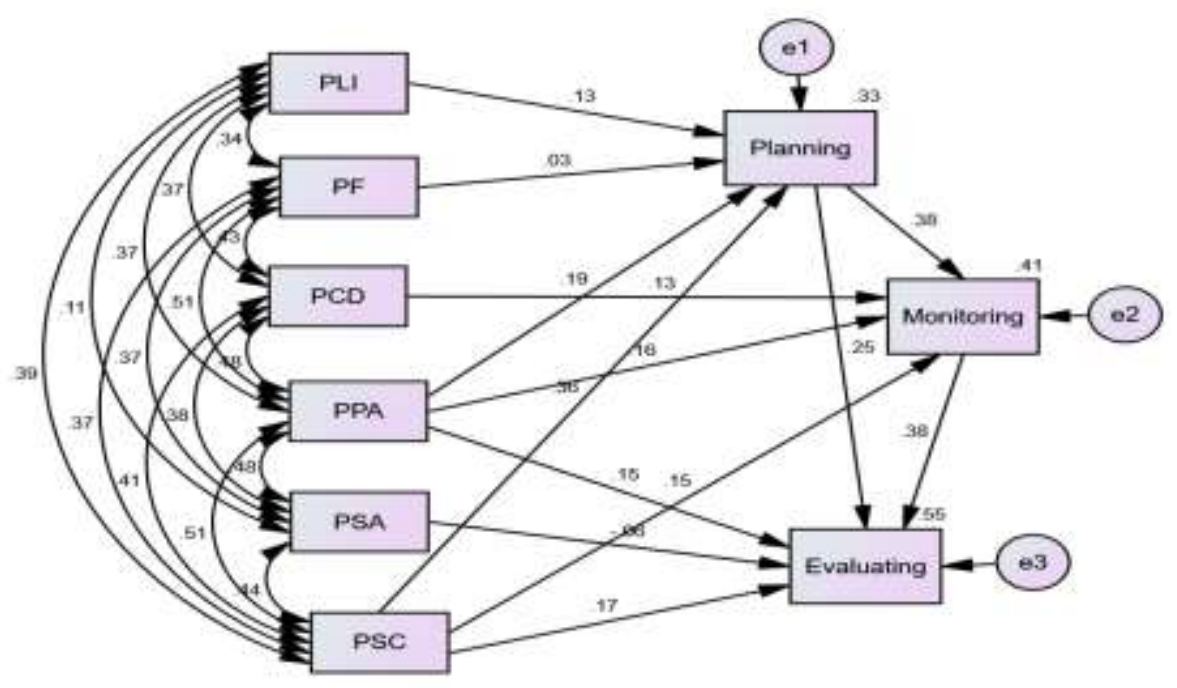

Figure 2

Standardized solutions of the structural model

(PLI-perceived learning intentions; PF-perceived feedback; PCD- perceived classroom discussion; PPA-perceived peer assessment; PSA-perceived self-assessment; PSCperceived success criteria; e-error terms)

\section{DISCUSSION}

This study aimed to establish the relationship between mathematics teachers' perceptions of formative assessment and metacognitive regulation using the TAFL-Q and MAIT. The first part of the research question involved examining the validity of the two questionnaires in the Kenyan context. A confirmatory factor analysis on a sample of 180 mathematics teachers showed that the TAFL-Q had a poor fit whereas the MAIT had a good fit for the sample. An exploratory factor analysis of the TAFL-Q using the same sample resulted in a six-factor structure consisting of 19 items from the original 28 items. The six-factor solution explained $66 \%$ of the total variance. The new structure was deemed suitable since every scale had at least three items with good reliabilities. Furthermore, the new factors were still in line with the theoretical framework of formative assessment (Black \& Wiliam, 2009). The new version of the TAFL-Q was subjected to a confirmatory factor analysis using a different sample of 213 mathematics teachers. The new structure resulted in an acceptable model with good fit indices. The confirmatory analysis of the three scales representing metacognitive regulation on the MAIT scale had good fit indices on both the first and the second samples. There was, therefore, no adjustment of the items.

Although the TAFL-Q has gained popularity in different cultural contexts, some studies that have used this questionnaire never examined the contextual suitability of the 
instrument. For instance, Öz (2014) used the questionnaire to measure the perceptions of Turkish English teachers but never reported about confirmatory factor analysis. Similarly, the same questionnaire was used in Tanzania without a confirmatory analysis of the factors (Kyaruzi et al., 2018). However, Nasr et al. (2018) found the questionnaire fit to measure the perceptions of Iranian English teachers. Due to cultural differences and different educational practices, questionnaires may not elicit similar structures across different samples (Brown, Harris, O'Quin \& Lane, 2017). It is therefore important to examine the structure of an existing scale when dealing with a different cultural context.

Several inventories have been used to conceptualize metacognition for the past four decades (e.g., Paris \& Jacobs, 1984; Miholic, 1994; Schraw \& Dennison, 1994; Balcikanli, 2011). The most widely used and cited in the literature is the Metacognitive Awareness Inventory (MAI) which was developed by Schraw and Dennison (1994) to measure the metacognitive awareness for adults. Since the focus was generally on adults, Balcikanli (2011) found it necessary to develop a metacognitive inventory that specifically measures teachers' metacognitive awareness. The MAIT was therefore simply a modification of the MAI to fit the teaching context. Although the MAIT has not been widely used, the original version (MAI) has proved its validity across different cultural contexts. The MAIT was found suitable for measuring the level of metacognitive skills among secondary school mathematics teachers in Kenya.

The second part of the research question involved assessing the relationship between teachers' perceptions of formative assessment and metacognitive regulation. The results showed a significant positive relationship between most of the factors. For instance, learning intentions (PLI), success criteria (PSC), and peer assessment (PPA) significantly predicted teachers evaluating skills. This implies that mathematics teachers develop evaluation skills when they use formative assessment strategies like sharing learning intentions and success criteria with students and engineering them as instructional resources of one another. Self-assessment did not, however, have a significant effect on teachers evaluating skills. Monitoring strategies were significantly predicted by classroom discussion (PCD) and peer assessment (PPA). Through classroom discussion and peer assessment, students can reflect and monitor their learning process. Planning strategies were significantly predicted by learning intentions (PLI), peer assessment (PPA), and success criteria (PSC). This shows that mathematics teachers' planning strategies are enhanced when they share learning intentions and success criteria with students. When the planning strategies are in place, it becomes easier for teachers to monitor and evaluate the learning. It's worth noting that among the predictors, peer assessment and success criteria had a significant effect on the three outcome variables of metacognitive skills. This underscores the importance of these formative assessment strategies in metacognitive regulation. Overall, the results were in line with our hypothesized relationship except for the relationship between selfassessment and evaluation which turned out to be negative although not significant. 


\section{CONCLUSION AND SUGGESTIONS}

The current study builds on the work of Black and Wiliam (2009), Pat-El et al. (2013), and Balcikanli (2011) to try and conceptualize the relationship between formative assessment and metacognitive regulation. Unlike metacognitive regulation which has been consistently conceptualized and widely measured, formative assessment (assessment for learning) was first measured instrumentally by Pat-El et al. (2013). Furthermore, only a few studies have measured the relationship between formative assessment and metacognitive regulation. The findings of our study show that monitoring and scaffolding dimensions as described by Pat-El et al. (2013) can be disintegrated into subcomponents of Learning Intentions; Feedback; Classroom Discussion; Peer Assessment; Self-Assessment and Success Criteria. Our results have shown that formative assessment strategies predict teachers' levels of metacognitive regulation. Baas et al. (2014) although using elementary school students similarly found out that formative assessment strategies predict metacognitive regulation.

There is a need for subsequent work to consider other variables of formative assessment and how they relate to metacognitive regulation. The work should also involve multiple approaches to measuring the constructs of formative assessment and metacognitive regulation. More research is needed to test the relationship exhibited in the present study with other samples, especially in different cultural contexts. The findings of this study will contribute to future theory development and designing effective intervention programs for classroom instruction.

\section{REFERENCES}

Balcikanli, C. (2011). Metacognitive awareness inventory for teachers (MAIT). Electronic Journal of Research in Educational Psychology, 9(3), 1309-1332.

Baas, D., Castelijns, J., Vermeulen, M., Martens, R., \& Segers, M. (2014). The relation between Assessment for Learning and elementary students' cognitive and metacognitive strategy use. British Journal of Educational Psychology, 85(1), 36-46. https://doi.org/10.1111/bjep.12058.

Ben-David, A., \& Orion, N. (2013). Teachers' voices on integrating metacognition into science education. International Journal of Science Education, 35 (18), 3161-3193. https://doi.org/10.1080/09500693.2012.697208.

Black, P., \& Wiliam, W. (2009). Developing the theory of formative assessment. Educational Assessment, Evaluation, and Accountability, 21, 5-31. DOI:10.1007/s11092-008-9068-5.

Black, P., \& Wiliam, D. (1998). Assessment and classroom learning: Assessment in Education: Principles, Policy \& Practice 5(1), 5-74. https://doi.org/10.1080/0969595980050102.

Braund, H., \& DeLuca, C. (2018). Elementary students as active agents in their learning: an empirical study of the connections between assessment practices and student 
metacognition. The Australian Educational Researcher, 45(1), 6585.https://doi.org/10.1007/s13384-018-0265-z.

Brown, A. L. (1978). Knowing when, where, and how to remember: A problem of metacognition. In R. Glaser (Ed.), Advances in instructional psychology, 1, 77-165. Hillsdale: Erlbaum.

Brown, G. T, Harris, L. R, O'Quin, C., \& Lane, K. E (2017). Using multi-group confirmatory factor analysis to evaluate cross-cultural research: identifying and understanding non-invariance. International Journal of Research \& Methodology in Education, 40 (1), 66-90. https://doi.org/10.1080/1743727X.2015.1070823.

Chan C. (2010). Assessment: Self and Peer Assessment. Assessment Resources@HKU, University of Hong Kong [http://ar.cetl.hku.hk].

Clark I (2012). Formative assessment: assessment is for self-regulated learning. Educ Psycho Rev 24, 205-249. DOI: 10.1007/s10648-011-9191-6.

Csíkos, C., \& Steklács, J. (2010). Metacognition-based reading intervention programs among fourth-grade Hungarian students. In Trends and Prospects in Metacognition Research (pp. 345-366). https://doi.org/10.1007/978-1-4419-6546-2_16.

Demetriou, A., Spanoudis, G., \& Mouyi, A. (2011). Educating the developing mind: Towards an overarching paradigm. Educational Psychology Review, 23(4), 601-663. https://doi.org/10.1007/s10648-011-9178-3

Flavell, J. H. (1979). Metacognition and cognitive monitoring. American Psychologist, $34,906-911$.

Gipps C, Hargreaves E, McCallum B (2015). What makes a good primary school teacher? Expert classroom strategies. London: Routledge.

Griffin, P., McGaw, B., \& Care, E. (2013). Assessment and Teaching of 21st Century Skills. Dordrecht, Germany: Springer Science+Business Media B.V. http://dx.doi.org/10.1007/978-94-007-2324-52.

Harris, K. R., Santangelo, T., \& Graham, S. (2010). Metacognition and Strategies instruction in Writing. In H. S. Schneider and W. Waters, Metacognition, Strategy Use, and Instruction, pp. 226-256. London, The Guilford Press.

Hattie, J., \& Yates, G. C. (2013). Visible learning and the science of how we learn. USA and Canada; Routledge.

Heritage, M. (2007). Formative assessment: What do teachers need to know and do? Phi Delta Kappan, 89(2), 140-145.

Ho R (2006). Handbook of univariate and multivariate data analysis and interpretation with SPSS. Chapman and Hall / CRC, Newyork.

Kline, R. (2011). Principles and practice of structural equation modeling, (2nd Ed.). New York: The Guilford Press. 
Kramarski, B., \& Mevarech, Z. R. (2003). Enhancing mathematical reasoning in the classroom: The effects of cooperative learning and metacognitive training. American Educational Research Journal, 40(1), 281-310. https://doi.org/10.3102/00028312040001281.

Kyaruzi F, Strijbos JW, Ufer S, Brown GT (2018). Teacher AfL perceptions and feedback practices in mathematics education among secondary schools in Tanzania. Studies in Educational Evaluation, 59, 1-9. https://doi.org/10.1016/j.stueduc.2018.01.004.

Lai, E. R., \& Viering, M. (2012). Assessing 21st-century skills: Integrating research findings. Vancouver: National Council on Measurement in Education.

Lee, I., \& Mak, P. (2014). Assessment as learning in the language classroom. Assessment as learning. Hong Kong: Education Bureau.

Mahdavi, M. (2014). An overview: Metacognition in education. International Journal of Multidisciplinary and Current Research, 2(6), 529-535.

Martinez, M. E. (2006). What is Metacognition? Phi Delta Kappan, 87(9), 696699. https://doi.org/10.1177/003172170608700916.

Mevarech, Z., \& Fridkin, S. The effects of IMPROVE on mathematical knowledge, mathematical reasoning, and meta-cognition. Metacognition Learning 1, 85-97. https://doi.org/10.1007/s11409-006-6584-X.

Miholic, V. (1994). An Inventory to Pique Students' Metacognitive Awareness of Reading Strategies. Journal of Reading, 38(2), 84-86.

Nasr, M., Bagheri, M. S., Sadighi, F., \& Rassaei, E. (2018). Iranian EFL teachers' perceptions of assessment for learning regarding monitoring and scaffolding practices as a function of their demographics. Cogent Education, 5(1), 1558916https://doi.org/10.1080/2331186X.2018.1558916.

Naseri, M., Kazemi, M. S., \& Motlag, M. E. (2017). The Effectiveness of metacognitive skills training on increasing academic achievement. Iranian journal of educational sociology, 1(3), 83-88.

OECD (2005). Formative Assessment: Improving Learning in Secondary Classrooms. Paris, ISBN: 92-64-00739-3. Retrieved on Nov 23, 2019, from, www.oecd.org/education/ceri/35661078.pdf.

Öz H (2014). Turkish Teachers' Practice of Assessment for Learning in English as a Foreign Language Classroom. Journal of Language Teaching \& Research, 5 (4). DOI:10.4304/jltr.5.4.775-785.

Paris, S. G., \& Jacobs, J. E. (1984). The benefits of informed instruction for children's reading awareness and comprehension skills. Child Development, 55(6), 20832093. https://doi.org/10.2307/1129781. 
Pat-El RJ, Tillema H, Segers M (2013). Validation of assessment for learning questionnaires for teachers and students. British Journal of Educational Psychology, 83 (1), 98-113. DOI:10.1111/j.2044-8279.2011.02057.

Pat-El, R. J., Tillema, H., Segers, M., \& Vedder, P. (2015). Multilevel predictors of differing perceptions of assessment for learning practices between teachers and students. Assessment in Education: Principles, Policy \& Practice, 22(2), 282-298. DOI: 10.1080/ 0969594X.2014.975675.

Panadero, E., \& Alonso-Tapia, J. (2014). How do students self-regulate? Review of Zimmerman's cyclical model of self-regulated learning. Anales De Psicología / Annals of Psychology, 30(2), 450-462. https://doi.org/10.6018/analesps.30.2.167221.

Panadero, E., \& Broadbent, J. (2018). Developing evaluative judgment: A self-regulated learning perspective. In D. Boud, R. Ajjawi, P. Dawson, \& J. Tai (Eds.), Developing evaluative judgment: Assessment for knowing and producing quality work. Abingdon: Routledge.

Roll, I., Aleven, V., McLaren, B. M., \& Koedinger, K. R. (2011). Improving students' help-seeking skills using metacognitive feedback in an intelligent tutoring system. Learning and instruction, 21(2), 267-280. https://doi.org/10.1016/j.learninstruc.2010.07.004.

Sadler, D.R. (2009) 'Indeterminacy in the use of preset criteria for assessment and grading in higher education', Assessment and Evaluation in Higher Education, 34: 15979. https://doi.org/10.1080/02602930801956059.

Schraw, G. (1998). Promoting general metacognitive awareness: Instructional Science 26: 113-125. DOI: 10.1023/A:1003044231033.

Schraw, G., \& Dennison, R. S. (1994). Assessing metacognitive awareness. Contemporary educational psychology, 19(4), 460-475. https://doi.org/10.1006/ceps.1994.1033.

Shepard, L.A. (2006). Classroom assessment. In R. L. Brennan (Ed.), Educational measurement ( $4^{\text {th }}$ ed., pp. 624-646). Westport, CT: Greenwood Publishing Group.

Shute, V. J., \& Becker, B. J. (2010). Prelude: Assessment for the 21st century. Innovative assessment for the 21st century (pp. 1-11). Springer, Boston, MA. https://doi.org/10.1007/978-1-4419-6530-1_1.

Tanner, K. (2012). Promoting student metacognition. CBE Lif SCi Educ 11,113-120. https://doi.org/10.1187/cbe.12-03-0033.

Veenman, M. V. J. (2011). Learning to self-monitor and self-regulate. In R.E. Mayer and P A. Alexander (Ed.), Handbook of Research on Learning and Instruction (PP 197218) Madison Avenue, New York: Routledge. 
Veenman, M. V. J., Wilhelm, P., \& Beishuizen, J. J. (2004). The relation between intellectual and metacognitive skills from a developmental perspective. Learning and Instruction, 14, 89-109. https://doi.org/10.1016/j.learninstruc.2003.10.004.

Veenman, M. V. J., Van Hout-Wolters, B. H. A. M., \& Afflerbach, P. (2006). Metacognition and learning: conceptual and methodological considerations. Metacognition and Learning, 1, 3-14. https://doi.org/10.1007/s11409-006-6893-0.

Vrugt, A., \& Oort, F. J. (2008). Metacognition, achievement goals, study strategies, and academic achievement: pathways to achievement. Metacognition and learning, 3(2), 123-146.DOIhttps://doi.org/10.1007/s11409-008-9022-4.

Wiliam, D. (2011). Embedded formative assessment. Bloomington, IN Solution Tree Press.

Williams, B., Onsman, A., \& Brown, T. (2010). Exploratory factor analysis: A five-step guide for novices. Australasian Journal of Paramedicine, 8 (3), 1-11. DOI: http://dx.doi.org/10.33151/ajp.8.3.93.

Williams, J. P., and Atkins J. G. (2009). The Role of Metacognition in Teaching Reading Comprehension to Primary Students. In D. J. Hacker, J. Dunlosky, and A. C. Graesser, Handbook of Metacognition in Education (pp. 26-44). New York: Routledge.

Zimmerman, B. J., \& Schunk, D. H. (2011). Self-regulated learning and performance: An introduction and an overview. In B. J. Zimmerman \& D. H. Schunk (Eds.), Educational psychology handbook series. Handbook of self-regulation of learning and performance (p. 1-12). Routledge/Taylor \& Francis Group. 